\title{
The Model of Turkish Foreign Policy: Opening New Horizons
}

\begin{abstract}
Seeking international authority Turkey uses a self-designed democracy model; therefore, this Muslim state has more possibilities to address societies of the Middle East region and propose to them a new paradigm concerning the future of these countries, thus guaranteeing their aspirations for justice and equality. Turkey is the only Muslim state with a functioning democracy, oriented towards the world of the West. The position of the political elite of Turkey concerning a vision for the country's modernization and its traditional Muslim society world outlook, reflects the compatibility of the internal development of the country. While analyzing the principles of Turkish foreign policy, the doctrine of the "Strategic Depth", the guidelines, tendencies, strategies, directions and visions of Turkish foreign policy, one may discern the possibilities of the use of doctrine principles, taking into consideration essential geopolitical changes of the $20^{\text {th }}$ and $21^{\text {st }}$ centuries. The issue of Turkey's accession to the European Union is a complicated and controversial aspect of the foreign policy of the EU. Therefore, an understanding of the decision-taking model of the Turkish political elite will enable European Union politicians (as well as those of Lithuania) to make clear substantiated decisions regarding this country.
\end{abstract}

\section{Introduction}

The European Union is seeking to become a global player in the international arena, yet the current situation clearly indicates that the effectiveness of the EU external actions and possibilities could be much more productive. The European security strategy, adopted in December 2003, clearly delineates the most important EU security policy standpoints and states that regional conflicts are one of the primary threats to EU security.

The strategic goal of the common foreign and security policy is to expand the security and stability zone around Europe; therefore, it is not

\footnotetext{
* Valerij Špak has a Master's degree in Political Science from the Military Diplomacy Program of the Military Academy of Lithuania. Address for correspondence: Šilo 5a, LT-10322 Vilnius, Lithuania, tel. +370-5- 2103569, e-mail: valerijspak@gmail.com
}

DOI: 10.2478/lasr-2014-0005

(C) Valerij Špak, 2014

(C) Military Academy of Lithuania, 2014 
surprising that the EU Council presented this in its strategy: "We should now take a stronger and more active interest in the problems of the Southern Caucasus." ${ }^{1}$ Certainly, with systemic Arab spring changes underway, the Middle East and North Africa are related to such regions. That is why, in the context of mediation and conflict regulation, Turkey is most often alluded to as an active player of the region. Quite a few scientists have paid attention to the capability of this state to perform an important role in settling regional conflicts and arguments, particularly in the two neighboring EU regions - the Middle East and South Caucasus. ${ }^{2}$ The current Minister of Foreign Affairs of Turkey, Ahmet Davutoğlu, proposes that "Turkey offers something unique to the EU as it could give it an enlarged geopolitical imagination and staging, which will allow the EU to be a global player..."3

The end of the bipolar world system became the most important systemic factor that granted acceleration to the search for a new mode of Turkish foreign policy. During this regulation process, Turkey had to develop new relations perspectives by seeking new concepts on the basis of which it could change the direction of its foreign policy. The vision of Turkish policy concerning the Middle East region was completely formed during the first decade of the twenty-first century. Because of the changes that took place in the regional geopolitical environment, Turkey began to consider the concept of Eurasia as one of the primary geopolitical concepts. By applying classical geopolitical methods of the West concerning Eurasia (starting with Halford Mackinder, Nicholas Spykman and finishing with Zbigniew Brzezinski), Turkish theorists tried to create a new geopolitical vision of the country, though in many cases assumptions they made differed greatly from the conclusions drawn by Western scientists.

During the recent decade, Turkey has markedly strengthened its political and economic influence not only on the neighboring regions but its significance has also become visible at the international level. This has triggered

\footnotetext{
${ }^{1}$ Council of European Union, „A Secure Europe in a Better World - European Security Strategy”, Brussels, 12 December 2003, p. 13, www.consilium.europa.eu/uedocs/cmsUpload/78367.pdf., 07-02-2013.

${ }^{2}$ Sedat Laçiner, Mehmet Özcan, İhsan Bal, European Union with Turkey. The Possible Impact of Turkey's Membership on the European Union, Ankara: ISRO, 2005, p. 15-86; Özlem Terzi, „Evolving European Security Capabilities and EU-Turkish Relations", Perceptions. Journal of International Affairs, vol. 9, no.1, March - May 2004, p. 99-118; Thanos Dokos, „Turkey and European Security”, in Constantine Avranitopoulos (ed.), Turkey's Accession to the European Union. An Unusual Candidacy, Berlin, Heidelberg: Springer Verlag, 2009, p. 75-85.

${ }^{3}$ Ahmet Davutoğlu, ,Turkish Foreign Policy and the EU in 2010”, Turkish Policy Quarterly, vol. 8, no. 3 (Fall 2009), p. 15, http://www.turkishpolicy.com/article/433/. Ahmet Davutoğlu: Türkiye Avrupa’nın Bir Parēasıdır" (Davutoğlu: Turkey is part of Europe), in Radikal, 17 February 2013, http://www.radikal.com. tr/Radikal.aspx?aType=RadikalD 07-02-2013.
} 
extensive intellectual discussions of academic and political layers about the aims and directions of Turkish foreign policy, its ever improving relations with neighbors. These relations have been determined by the changing foreign policy of Turkey with the help of "soft power" leverages and a constructive dialogue.

In the West, mostly in Europe, the political life of Turkey and decisions by its foreign policy makers are most often assessed by surveying the course of the negotiations pertaining to the accession to the EU process. According to Talip Küçükcan and Müjge Küçükkeleş, “Turkey’s historical identification with Europe, and its continuing attempt to join the EU, has made most people in Turkey define the West with Europe. Yet, debates over how the West views the continuity and change in the AK Party's (Adalet ve Kalkinma Partisi, further AKP) foreign policy, have mostly focused on American viewpoints." Turkey has been defined as a "lost ally", whereas its Eastern policy has been considered to be competing with US interests in the Middle East. The uncertainty of EU political functionaries, in terms of Turkish foreign policy direction, contributes significantly to this attitude. It is as complicated to discuss the would-be relations of the economic and strategic cohesion between the EU and Turkey. The form which the relations between the EU and Turkey may take is not clear so far, but it is necessary to seek applicable means that would be beneficial for both the parties and at the same time would enhance the probability of a positive scenario in the future.

The change in the political situation in the Middle East during the recent several years makes both the West and the countries of this region to well consider each step in seeking stability. Thus, the question whether this change can determine the ambiguous and sometimes misleading perception of Western politicians about the modern foreign policy of Turkey remains open.

The objective of this article is to provide and assess the characteristics of modern foreign policy of Turkey in the context of the changing global political situation.

The article will analyze the essence of the "Strategic Depth" doctrine, tendencies, strategies, directions and the vision pertaining to the foreign policy of Turkey. This is associated with the principles of "Security-Freedom Balance"; "Zero Problems with Neighbors"; "Multi-dimensional Policy or Policy of Multiple Vectors"; "Proactive Diplomacy" and "Rhythmic Diplomacy". Taking into consideration the essential geopolitical changes of the $20^{\text {th }}$ and $21^{\text {st }}$ centuries,

\footnotetext{
${ }^{4}$ Küçükcan T., Küçükkeleş M., European Views of Turkish Foreign Policy. Insight Turkey, Vol. 15, No. 1, p. 127, 2013, http://newsletter.setav.org/en/Mail/insight-turkey-vol-15-no-1-2013.aspx, 07-02-2013.
} 
the author will discuss the guidelines of Turkish foreign policy and the use of the principles of the "Strategic Depth" doctrine in relations with different states.

\section{Historical Premises of Modern Turkish Foreign Policy}

The end of the Cold War and a prolonged search for a new world order have brought to light the importance of the geopolitical position of Turkey - a state situated between Europe and Asia - for the security of the region. As Bülent Aras and Hakan Fidan have pointed out, the geographical position of the country can grant it extra leverage which policy makers should be aware of, assess and control while redefining" potential enemies as potential allies and a previous zone of conflict as a potential area of influence. Such changes reflect a distinct form of relationship between power and geography". Taking into consideration the exceptionality of Turkey's geopolitical position, Davutoğlu, a theorist of Turkish foreign policy, has widely referred to the ideas of geopolitical concepts. The main feature of geopolitical concepts (schemes) is the postulation of the dichotomy between sea and land (continental) powers. States are divided into two different zones as to their geopolitical position and civilization-related ideological values. At the end of the twentieth century the concept of Eurasia occupied a significant place in Turkish political discussions. It was perceived as one of the key concepts, reflecting the geopolitical strategy, international relations and national security of Turkey.

Mackinder, one of the first geopolitical theorists, has extensively substantiated and with the help of schemes represented the importance of geographical factors for the geopolitical tendencies of states, regions and even continents. ${ }^{6}$ He claims that in the continental part of Eurasia there is a geopolitical 'Heartland'. The Heartland is encircled by an inner (or peripheral/'Rimland') crescent to which such countries as Western and Central Europe and a part of Eastern Europe, the Middle and Central East, India, Indochina and China belong. The American geopolitician Spykman has taken over the main elements of the Mackinder scheme (the opposition between sea and continental states, the concept of the Heartland); however, he has essentially transformed this scheme (Fig.1).

\footnotetext{
${ }^{5}$ Bülent, Aras; Fidan, Hakan. “Turkey and Eurasia: Frontiers of a new geographic imagination”, New Perspectives on Turkey, no. 40, 2009, p. 196.

${ }^{6}$ Laurinavičius Č., Motieka E., Statkus N., Baltijos valstybių geopolitikos bruožai. XX amžius, Vilnius:

Lietuvos istorijos institutas, 2005, p. 32.
} 

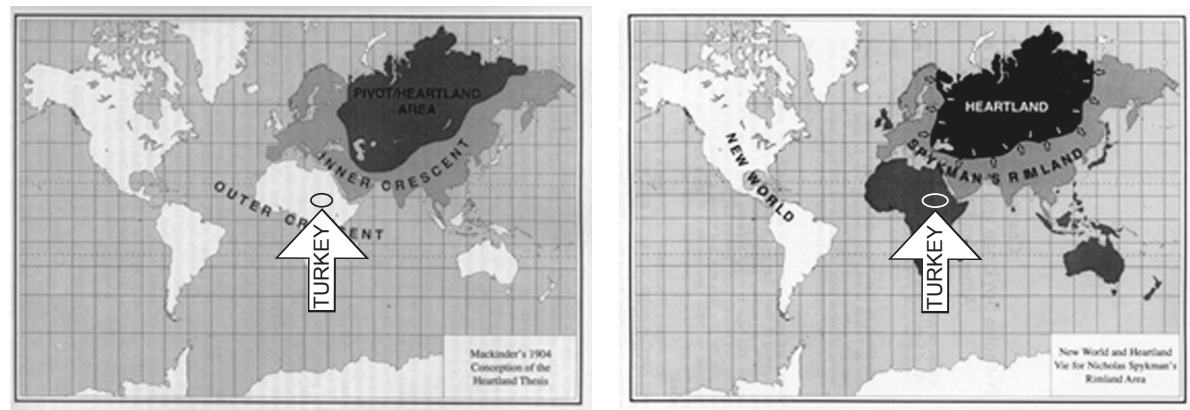

Figure 1. Boundaries of the heartland and rimland according to H. Mackinder (a) and N. Spykman (b) ${ }^{7^{*}}$.

"In Spykman's opinion, from the geopolitical point of view (and on the basis of the historical past) the most important position is taken by the Rimland (the costal or peripheral/Rimland zone). The Rimland zone is a broad zone between the Central part and sea powers". ${ }^{8}$ It comprises Scandinavia, Western, Central and Eastern Europe, a possibility to expand into China, the Middle East and Western Europe. During the Cold War period, Spykman's scheme became the basis of the USA's geopolitical code, "a central theoretical foundation of George F. Kennan's famous postwar proposal for the 'policy of containment' of the Soviet Union." ${ }^{\prime}$ From the ideological point of view, this doctrine manifested itself as a setback for communism. However, the geopolitical undercurrent meant the traditional fight of sea powers (primarily the USA) against the Heartland (the USSR or Russia). Spykman states: "Who controls the Rimland rules Eurasia; who rules Eurasia controls the destinies of the world"10. The containment policy of the US aimed to control this Rimland so as to neutralize the power of the Heartland, which was then under the control of the USSR. ${ }^{11}$ Taking into account the above mentioned concepts, Turkey in classical geopolitics is ascribed the role of a Rimland/peripheral country. Since Turkey is under the influence of the Western bloc, keeping in mind the defence of the south-eastern flank, it was assigned a barrier role, i.e. a reliable and strong watchman (in other words, a gendarme). This helped abolish the

\footnotetext{
$7^{*}$ Source: http://www.ggarchive.org/articles/globalist-map-room.html, http://www.oldenburger.us/gary/ docs/TheColdWar.htm.

${ }^{8}$ Laurinavičius Č., Motieka E., Statkus N., Baltijos valstybių geopolitikos bruožai. XX amžius, Vilnius: Lietuvos istorijos institutas, 2005, p. 39-40.

${ }^{9}$ Wilkinson, David. Spykman and Geopolitics. of Ciro E. Zoppo and Charles Zorgbibe, eds., On Geopolitics: Classical and Nuclear. Dordrecht: Martinus Nijhoff, 1985, p. 77 - 129.

${ }^{10}$ Nicholas J. Spykman. The Geography of Peace. New York. Harcourt \& Brace, 1944, p. 43.

${ }^{11}$ Davutoğlu Ahmet, “The Clash of interests: an explanation of the world (dis)order”, Journal of international affairs. December 1997-February 1998, vol. II, no. 4.
} 
continental power of Eurasia aimed at seeking geo-economic resources of the Middle East and geopolitical potential of the Rimland.

Responding to the threats associated with the Soviet Union, Turkey was forced to choose an all-embracing coordination and integration with the West. Therefore, Turkey's westernization (shaping of policy oriented towards the West) could be considered a process which established a corresponding security strategy in order to guarantee the survival of the Republic. And the born "military and economic dependency which meant a sustained US material hegemony, brought a complete and voluntary abandonment of some traditional foreign policy attitudes like balance politics and pro-status quo line...(while retaining the established order and balance as well as the existing borders with the neighbors)" ${ }^{12}$ Foreign policy key goals were "limited to the sovereignty and territorial integrity of the state". 13

The origin of the fear of losing territorial integrity is related to the Sèvres Treaty (1920) that dissolved the Ottoman Empire. In compliance with this treaty, Turkey was divided between the Western powers and Christian minorities cooperating with them. The results of the treaty caused the emergence of the so-called Sèvres syndrome. The latter is associated with the conviction that the outer world is secretly planning to weaken and divide Turkey. "The culture of Turkish national security, greatly influenced by the military, stressed the mentality and analyses based on "Sèvres syndrome". ${ }^{14}$ Davutoğlu defines the Sevres treaty as the "bottleneck" which the founders of Turkish Republic had to go through. According to Davutoğlu, this bottleneck had happened at one point and had already been overcome and there is no need to live with yet no falling into lethargy of defeating the West and forgetting the severe lessons learnt under either. Psychological level that causes a defensive attitude, it certainly hinders our power and paves the way for new Sevres - like treaties ${ }^{15}$

The present-day skepticism in Turkey, according to Yilmaz Hakan, is a reflection of Tanzimat (the objective of the Tanzimat reforms is to grant the subjects of the Ottoman Empire contemporary civil rights and establish a state based on the principles of a legal state) and Sèvres syndromes and constitutes the

\footnotetext{
${ }^{12}$ Özlem Kaygusuz. "Securitization in the context of global hegemony: US-Turkish relations in perspective”. Mersin University Department of International Relations, 2005. p. 17, http://turin.sgir.eu/uploads/ Kaygusuz-TurinKaygusuz.pdf.

${ }^{13}$ Jung D. “The Sèvres Syndrome: Turkish Foreign Policy and its Historical Legacy”, http://www.unc.edu/ depts/diplomat/archives_roll/2003_07-09/jung_sevres/jung_sevres.html.

${ }^{14}$ Kemal Kirisci, “Turkey and the United States: Ambivalent Allies”, MERIA, vol. 2, no. 4, December 1998, p. 42.

${ }^{15}$ Davutoğlu Ahmet. Stratejik Derinlik: Türkiye’nin Uluslarası Konumu, İstanbul: Küre Yayinlari. 2001, p. 61.
} 
nucleus of the Turkish national discourse in Europe ${ }^{16}$. He states that at the time when "deep policy" imperative of the Tanzimat syndrome is a delegitimation of collective and individual rights, that of the Sèvres is a isolationism in the area of foreign policy and "westernization without the West" in the domestic arena ${ }^{17}$. The exploration of these two syndromes makes it possible to reveal the premises for the emergence of the national conservatism towards a strategic shift.

The dissolution of the bipolar system of global international relations was followed by a geopolitical vacuum that caused the inconsistency of international relations. This factor provided a possibility for regional powers to fill up the huge vacuum that created the "geo-strategically very important zone where the Heartland and the Rimland intersect". ${ }^{18}$ One can discern certain tendencies indicating that most military and political crises after the Cold War took place in this particular zone (e.g. in the Balkans, the Persian Gulf).

Ahmet Sözen claims that "the end of the Cold War which can be termed as a paradigmatic shift at the systemic level provided Turkey with new opportunities together with lots of uncertainties with potential threats". ${ }^{19}$ This situation provided Turkey the possibility to undertake a new role at the international level and to expand foreign policy horizons. In other words, with the relations being problematic there appeared more room for tactical maneuvers of Turkish foreign policy and more time to be allotted to actual problems and the development of a new strategy. According to Brzezinski, Turkey, like Iran, has always been an important geopolitical center, which stabilizes the Black Sea region ${ }^{20}$, controls the access to the Mediterranean Sea, suppresses Russian influence in the Caucasus and still remains the equilibrium in terms of Muslim fundamentalism. It is on the domestic situation in Turkey that in most cases, the future of the entire region depends. Therefore, it is possible to claim that future perspectives of the Caucasian states will depend on the direction of domestic and foreign policy of Turkey. If Turkey persistently follows its way to Europe, the Caucasian region states will also have the possibility to enter the area of European influence.

\footnotetext{
${ }^{16}$ Yilmaz, Hakan, Two Pillars of Nationalist Euroskepticism in Turkey: The Tanzimat and Sevres Syndromes. In Ingmar Karlsson and Annika Strom Melin, eds., Turkey, Sweden and the European Union: Experiences and Expectations, Stockholm: SIEPS (Swedish Institute for European Policy Studies), 2006, p. 29 - 40. ${ }^{17}$ Yilmaz, Hakan, Two Pillars of Nationalist Euroskepticism in Turkey: The Tanzimat and Sevres Syndromes. In Ingmar Karlsson and Annika Strom Melin, eds., Turkey, Sweden and the European Union: Experiences and Expectations, Stockholm: SIEPS (Swedish Institute for European Policy Studies), 2006, p. 29.

${ }^{18}$ Davutoğlu, (note 9). p. 114.

${ }^{19}$ Sözen Ahmet. Changing Fundamental Principles in Turkish Foreign Policy Making of International Relations Eastern Mediterranean University (North Cyprus) Paper prepared for presentation at the 2006 Annual Conference of the International Studies Association in San Diego, USA, March. p. 23.

${ }^{20}$ Бжезинский 3. Великая шахматная доска (Господство Америки и его геостратегические императивы). М.: Междунар. отношения, 1998, р. 27.
} 
But if due to external or internal reasons the Europeanization of Turkey suffers a failure, the states of the region will have no other choice but to get adjusted to Russia's interests and depend on the development of the factual relations of Russia with expanding Europe.

\section{The "Strategic Depth" Doctrine as a Geopolitical Concept}

Analyzing the geopolitical position of Turkey, Davutoğlu supported Brzezinski's idea concerning Turkey's possibility to be a regional center. A thorough analysis of its geographical, historical and cultural legacy enabled him to gain deeper insight into Turkey and describe it as a central state. The statement about the central position is the most significant premise of the "Strategic Depth" doctrine. Davutoğlu also took into account the remarks of Alfred Thauer Mahan, who paid special attention to the geographical position of states. He pointed out that the geographical position yields a great advantage, enabling it to control the choke points which divide the warm seas of the world ${ }^{21}$. Even "the fact that eight out of the sixteen strategically most important choke points - the Suez Canal, Bab el-Mandeb (the exit from the Red Sea), the Strait of Hormuz (the exit from the Persian Gulf), the Strait of Malacca, the Sunda Strait (between Sumatra and Java), the Lombok Strait (between Bali and Mataram), and the Bosphorus and Dardanelles (exits from the Black Sea) - are under the full control of Muslim countries, while one of them (the Strait of Gibraltar) separates a Muslim state (Morocco) and a European state (Spain)".22

A favorable international situation enabled the formation of new Turkish foreign policy directions and priorities which paid great attention to the holistic awareness of historical tendencies - the uniqueness of historical experience, geographical position, the influence on the implementation of national interests and on the development of the rich cultural and intellectual legacy. Taking into consideration the multidimensional context of the development of international relations, Turkey could begin to implement such a concept of foreign policy which would reflect its ambition to become not only a regional but also a global leader.

Turkey's traditional foreign policy rhetoric noticeably changed during the

\footnotetext{
${ }^{21}$ Davutoğlu Ahmet, "The Clash of interests: an explanation of the world (dis)order", Journal of international affairs. December 1997-February 1998, vol. II, no. 4., p. 9.

${ }^{22}$ Murinson A.. The Strategic Depth Doctrine of Turkish Foreign Policy. Middle Eastern Studies, Vol. 42, 2006, No. 6. http://www.olympiaseminars.org/2012/readings/Cycle_B/murinson-strategicdepthdoctrine. pdf, 06-10-2013. p. 949.
} 
reigning era of the AKP, and new concepts that were introduced reflect these changes most distinctly. Davutoğlu was one of the first to define the guidelines of the Turkish foreign policy doctrine. In his most notable academic work the "Strategic Depth" (In Turkish: Strategik Derinlik, Turkiyenin Uluslararasi Копити) he presented the perspective of Turkey concerning its immediate neighbors. ${ }^{23}$ The essence of this work is the historical, geopolitical, economic, international analysis of Turkey's position and foreign policy vision, revealing the core of its interests and contradictions. Davutoğlu reinterprets the mission and interests of Turkey as a global mediator and peacekeeper in the world. The fundamental foreign policy philosophy of Davutoğlu reads - "self-perception is one of the most specific and sophisticated concepts that represent the transformation in Turkish foreign policy. [...] it was one of the central concepts in his criticism of the "shallow" territorial and geographical perception of Turkey in the Cold War era. [...] This concept has been immensely influential in transforming Turkey's traditional perception". ${ }^{24}$ Taking into account the central position of Turkey, the goal of the "Strategic Depth" doctrine was to underline the new role of Turkey in neighboring countries and in international politics.

In terms of geography, Turkey occupies a unique space. Davutoğlu writes: "As a large country in the midst of Afro-Eurasia's vast landmass, it may be defined as a central country with multiple regional identities that cannot be reduced to one unified character. [...] Turkey cannot be explained geographically or culturally by associating it with one single region". ${ }^{25}$

In seeking a new role in the international arena, the election, held in November of 2002 and won by the AKP, was an important stimulus. This party was capable of perceiving and addressing not only political but also social and economic domestic problems, meanwhile executing the launched liberal reforms. The AKP political program incorporated the majority opinion that Turkey takes not a peripheral but central position on the international arena. Such a position could be taken by relying on the geopolitical vision and active aspiration of the AKP foreign policy to gain independence and confidence in its capability.

The purpose of the "Strategic Depth" conception is the aspiration to delimit Turkey's dependence on the West by paying the greatest attention to multisided unions in order to maintain balance in the region. The main premise states that Turkey should not be dependent on a single international actor; therefore, it should actively look for ways to balance its relations and

\footnotetext{
${ }^{23}$ Davutoğlu, (note 13$)$.

${ }^{24}$ Yeşiltaş M., Balcı A.. A Dictionary of Turkish Foreign Policy in the AK Party Era: A Conceptual Map, Sakarya University, SAM Papers, 2013, May, No. 7. p. 7.

${ }^{25}$ Ahmet Davutoğlu, “Turkey's New Foreign Policy Vision,” Insight Turkey 10, No.1 (2008), p. 78.
} 
unions meanwhile maintaining optimal independence and impact on the global and regional space. Turkey has regional powers due to the fostering of strong statehood traditions. Davutoğlu emphasizes that "he also stresses a shift in geopolitical status of Turkey from a barrier, predicated on its NATO membership during the cold war, to a bridge to a new regional system, which extends beyond Erzurum Plain and includes states of the Caucasus and Eurasia. He also notes that the concept of the 'continental basin' allows Turkey to gain 'strategic depth in Asia, and projection into Europe and Africa."'26

Historical and cultural ties with the neighboring regions determine Turkey's strategic foreign policy potential to the creation of which the development of democratic institutions and flourishing market economy largely contribute. The militaristic image that dominated in its political history has been replaced by searching for solutions to regional conflicts and economic cooperation. According to Davutoğlu: "... Turkey enjoys multiple regional identities and thus has the capability as well as the responsibility to follow an integrated and multidimensional foreign policy. The unique combination of our history and geography brings with it a sense of responsibility. To contribute actively towards conflict resolution and international peace and security in all these areas is a call of duty arising from the depths of a multidimensional history for Turkey."27

\section{Table 1. Political Significance of the "Strategic Depth" Doctrine}

\section{Historical unions of Turkey reconsolidate:}

- traditional allies, for example, the USA and Europe, are important; however, the greatest attention is paid to the former "foreign" neighbors, for example, Russia and Iran;

- new alliances with strengthening states, such as China and India which help decrease Turkey's dependence on the West.

2. Searching for geopolitical identity by identifying with the former Ottoman Empire;

- revived interest in former Muslim colonies with Turkey "returning" to the Middle East and allotting a special attention to Syria and Iraq;

- assuming a greater responsibility for the regional stability in the Balkans by operating with new allies, such as Serbia and Russia and by rejecting NATO commitments;

- searching for solutions to historical differences and enhancing cooperation with Armenia.

3. Extension of influence beyond the boundaries of the Ottoman Empire:

- an accentuated role of Turkey in the Muslim world: establishment of historical relations with Afghanistan and Pakistan, also maintenance of closer relations with distant countries such as Malaysia or Indonesia;

- involvement of Central Asia and suggestion of an economic development model through Turkey's enterprises, educational and non-governmental organizations (further - NGOs).

\footnotetext{
${ }^{26}$ Murinson, (note 18), p. 952.

${ }^{27}$ Iloannis N. Grigoriadis, The Davutoğlu Doctrine and Turkish Foreign Policy, Bilkent University / ELIAMEP. Working Paper No 8/2010. p. 5.
} 
The "Strategic Depth" doctrine calls for active engagement of Turkey with all neighboring states of the region. According to Davutoğlu, Turkey had to rediscover its historical and geographical identity and to reassess its position, taking into account regional and global problems. This allowed Turkey to form an active foreign policy and determine the projection of its axis. Prime Minister of Turkey, Recep Tayyip Erdogan underlined that it is particularly important to ensure tight social, economic, cultural ties with all regional states, so that Turkey would remain an international level player globally. Therefore, the chosen Turkish foreign policy strategies were being implemented not only theoretically but also practically. This assisted the AKP in working with many national and most zealous secularists since it did not try to neglect the past mistakes of the Ottoman Empire or the previous impact on the most significant historical events. In assessing the suggested perception of Turkey's foreign policy role in the international arena, it should be pointed out that it has changed not only at the national and regional but also at the international level.

\section{Key Principles of Turkish Foreign Policy}

Traditional Turkish foreign policy formulations have been based on: “... the historical experience of the Ottoman Empire (the tradition of the balance of power); the nationalist Kemalist revolution and creation of the republic itself (hence, isolationism); western orientation expressed in the policy of Europeanization and modernization; the suspicion of foreign powers and interests (the Sèvres syndrome)." ${ }^{28}$

However, the new geopolitical reality made Turkish politicians reconsider strategic interests and priorities of the country. Unlike the early static and mono-dimensional strategy, the vision of the AKP foreign policy was based on the possibilities of Turkey to play an important role in constructing a new political, economic and cultural system. Thus, the necessity of Davutoğlu's "Strategic Depth" doctrine, which is based on five fundamental principles of foreign policy, served the purpose. By ensuring the creation of the zone of geopolitical security and stability around Turkey, the basic principles of the "Strategic Depth" doctrine should be considered the principles of "zero problems with neighbors", "security and freedom balance" whose range of action receives most criticism. Given the geopolitical changes, possibilities of application of these principles cause controversy in their assessment.

\footnotetext{
${ }^{28}$ Murinson, (note 18), p. 945.
} 
"Security-Freedom Balance or balance between security and democracy" (in some cases, "security and democracy balance" - author's note) is a political principle which states that Turkish security must be understood more broadly without stifling inherent personal freedoms and rights.

The entire history of Turkish democratization in general does not reflect the balance between civil (civilian) and military relations. Until quite recently, the Turkish mindset was dominated by the belief that in order to have a safe country, restrictions could be placed on people's inherent freedoms, thus ensuring their security. ${ }^{29}$ Awareness of threat as a primary necessity isolated Turkey from its Eastern neighbors and granted the authorities a legitimate reason to impose violence and unnecessary restrictions on freedoms. Giving justification for the deceitful security motives related to excessive restrictions of personal rights and freedoms, the state was balancing on the edge of authoritarian regime.

In Davutoğlu’s opinion, "security-freedom balance" ensures stability within the country, and this is important for a successful foreign policy and vice versa. States that are not capable of organizing their internal affairs well cannot maintain a consistent position in developing international relations, because domestic problems may hinder setting strategic goals of the country's foreign policy.

In the "Strategic Depth" doctrine, Davutoğlu pointed out that the balance between security and democracy is essential since the most important task of the state remains the insurance and protection of inherent human rights and freedoms. According to him, "The legitimacy of any political regime comes from its ability to provide security to its citizens; this security should not be at the expense of freedoms and human rights in the country". ${ }^{30}$ The balance between security and freedom becomes a key tool for the coordination of competitive values or interests of states, although this is hardly possible without the authorities' interference.

In 2002, when the AKP came to power, major changes within the country took place, in service of the so-called Copenhagen political criteria of democracy and human rights. Therefore, "At the core of this have been seven constitutional reform packages, adopted between 2001 and 2003. Among the reforms are the abolishment of the death penalty during peace, the granting of cultural right to the Kurdish minority (TRT, the Turkish state broadcaster,

\footnotetext{
${ }^{29}$ Davutoğlu A.. Turkey’s Zero-Problems Foreign Policy. May 20, 2010.

${ }^{30}$ Davutoğlu A.,'Turkey's Foreign Policy Vision: An Assessment of 2007”. Insight Turkey Vol. 10 / No. 1 / 2008, p. 79.
} 
transmitted its first program in Kurdish on 9 June 2004, although the political significance of this is contested), [...] and provisions for the increased equality of men and women. At the same time, Turkey's economy underwent a series of reforms leading to a relative stabilization of the Turkish Lira." ${ }^{31}$

Legal acts regulating freedoms of meetings and associations were adjusted to EU standards, but the requirement to change the structure of strict legal foundations was not satisfied by political parties and trade unions. A democratic atmosphere is prerequisite for the development of such different movements as non-governmental organizations (further - NGOs) that often act as important groups making influence on democracy development in the country. However, in Turkey the perception of "national security" does not yet guarantee such possibilities for all operating NGOs. National security is often referred to even under insignificant circumstances, and this may become a serious problem that cannot be explained by routine decisions made by legislators and bureaucrats.

In 2005, Prime Minister Erdoğan clearly stated that in Turkey "Copenhagen Criteria cannot be transgressed as Turkey makes legal arrangements in the subject of the fight against terror" ${ }^{32}$, although the process of establishing democracy in the country is still underway, establishing the balance between freedom and security. This is indicated by the recent democratization processes, the so-called "street politics" which so far has not been very efficient, until the protests about Gezi Park took place. Ceyhun Cicekci claims that "...globalization and its technological returns have simply changed the nature of doing political demonstrations and enormously increased their capacity of attraction. The Gezi Park protests repeatedly demonstrated that the democratization is not totally a part of the governmental agenda, it could also be started from the individual level." ${ }^{33}$

Nevertheless, it helped to highlight drawbacks of the implementation of the constitutional law on peaceful organization of demonstrations and meetings. First, as has already been mentioned, in Turkish legal acts there still exist too broad administrational restrictions on the arranging of general meetings, such as organization of demonstrations in certain areas that are

\footnotetext{
${ }^{31}$ Thomas Diez, Turkey, the European Union and Security Complexes Revisited Paper for presentation at the Second Pan-European Conference on European Union, organised by the ECPR Standing Group on European Union, Bologna, 24-26 June 2004, p. 4 - 5.

${ }^{32}$ Erdogan R. T., No Stepping Back from the Copenhagen Criteria in the Fight against Terror. 14 September 2005. http://www.todayszaman.com/columnist-24050-erdogan-no-stepping-back-from-the-copenhagen-criteria-in-the-fight-against-terror.html, 24-06-2013.

${ }^{33}$ Cicekci C., An Interpretation of the Gezi Park protests in Turkey, http://www.academia.edu/4026657/ An_Interpretation_of_the_Gezi_Park_protests_in_Turkey, 18-07-2013.
} 
absolutely unsuitable to this end. In addition, in the vicinity of Gezi Park there was a lot of excessive police brutality, disruptive action against demonstrations and disproportionate use of force against the protestors. However, in spite of political "mistakes", the Gezi Park protests expressed a peculiar political position of the citizens which did not represent the current authorities. And "pluralist democracy is also claimed in some small party programmes; however, they have not got into the parliament up to now. These protests (if not to consider the excessive police force - the author's note), without an umbrella of any political party, revealed a political synergy that is based upon the pluralist democracy demands". ${ }^{34}$ Therefore, it may be said that having valuable experience of democracy, Turkey is entering a new phase of democracy not as a political elite or party but as an independent society in general.

However, while Turkey is balancing between inner and international political factors, there exist two specific problematic aspects:

- undemocratic challenges associated with the domestic political system and culture which have been discussed earlier;

- the way to become a member of the EU.

At this period, the integration of Turkey into Europe still remains very important for Turkish democratization with respect to continuity of a process already begun, and, consequently, for the new foreign policy vision formed by a strong position. For example, supporters of Turkey EU membership claim that, being a member of the EU, this state may help it to become a global player; among other benefits, this Muslim country may be a perfect mediator when settling regional conflicts, particularly in the Middle East and South Caucasus. One may doubt such statements, however. Perhaps, having become a member of the EU, Turkey will help solve conflicts, but only to a certain extent. First of all, "Turkey would have to counteract long and short term domestic and regional problems as well as the EU's weaknesses as an international actor". ${ }^{35}$ Also, Turkey's contribution to the strengthening of the EU role in managing conflicts in its neighborhood causes problems of impartiality and reliability of Turkish foreign policy. That is why the possible rejection of Turkey's membership due to identity problems is apparently based on deeper reasons between Turkey and countries opposing Turkey's membership. Having put aside the identity issue as the main reason for the disagreement between EU members on Turkey's accession, other no less urgent and controversial issues

\footnotetext{
${ }^{34}$ Ibid, p. 4.

${ }^{35}$ Szymanski A., Turkey's potential added value. to the EU: resolution of regional conflicts, Turkish policy quarterly Volume 8 Number 3, p. 125.
} 
in the context of Turkey and Europe remain, for example, the Cyprus issue. This shows that domestic peace and stability, continuity of modern and strong democracy as well as efficiency of the foreign policy vision is essential to future achievements of Turkish foreign policy.

The "zero problems with neighbors" principle guarantees maximum cooperation oriented towards relations with neighboring countries. Turkey's indifference to the region during the Cold War and its security policy did not mean that it had never been involved in processes of regional policy, although it had been distanced from the region. This happened because in the Middle East "Turkey had been seen as a Western satellite in the Middle East or a 'frontier outpost". 36

According to William Hale and Ergun Özbudun, "two main reasons for the failure to achieve an optimal outcome in the region should be highlighted. First of all, there was an uncertainty across the region and mistrust between states. Uncertainty was high because each statelacked reliable information about the intentions of its neighbors. Turkish traditional republican policymakers were, thus, extremely suspicious and cautious about their neighbor." ${ }^{37}$

Kadri Kaan Renda declares, that the "most of these neighbors were perceived to be the usual suspects who were not only giving political support to secessionist and fundamentalist terrorist organizations in Turkey but also clandestinely supplying them arms, hosting terrorist training camps, and even providing refuge to militants. [...] Turkey pursued an extremely cautious, if not paranoid, foreign policy that favored a security-oriented heavy-handed approach over a welfare-oriented cooperative approach". ${ }^{38}$

Short-sighted interests inherited from the Cold War time were shaped by zero sum mentality and dominated among strategists of Turkish policy, and their repercussion was the revival and enforcement of security issues. At that time, Turkey lacked a strong hierarchy associated with the settling of military and political issues as well as the strategy for solving economic and social issues in order to develop cooperation between countries within the region as well.

The "zero problems with neighbors" principle reflects Mustafa Kemal Atatürk's words: "Peace at home, peace in the world." Being directly related to other principles of foreign policy, the concept of zero problems with neighbors draws on six pillars:

\footnotetext{
${ }^{36}$ Cem I. Turkey in the New Century: Speeches and Texts Presented at International Fora (1995-2001). Expanded 2nd Edition ed.; Mersin and Nicosia: Rüstem Publishing. 2001. p. 32.

${ }^{37}$ William Hale; Ergun Özbudun. Islamism, Democracy and Liberalism in Turkey: The Case of the AKP. London and New York: Routledge, 2010. p. 120.

${ }^{38}$ Renda Kaan K., “Turkey’s Neighborhood Policy: An Emerging Complex Interdependence?” Insight Turkey vol. 13, no. 1/2011, p. 94.
} 
- equal security for all,

- economic integration,

- coexistence of different cultures in a respectful manner,

- a high-level political cooperation,

- a high-level of regional consciousness, and

- understanding the relationship between security and stability and development. ${ }^{39}$

Davutoğlu claims that "Turkey should appropriate a new position in its region by providing security and stability not only for itself but also for its neighbors and the region" ${ }^{40}$ Ankara has focused on the Balkans, the Middle East and Central Asia, i.e. areas having common cultural and historical links, with the intention of putting an end to the stage of alienation among the states of the region. Priority has been given to "soft power" application in the region, at the same time maintaining both economic potential and military influence. It is possible to state that in this respect Turkish foreign policy has become the continuation of domestic policy since a lot of things depend on the ability to solve internal problems in a timely manner. The events of 2007, when internal economic or political crises were encountered, were evidence of that. While arranging regular high-level meetings with neighboring countries, the AKP government was simultaneously promoting closer relations in all aspects, including the development of cultural, economic, social relations.

The "zero problems with neighbors" principle received the most criticism, since in any case it is impossible to completely avoid problems with neighbors. However, the difference lies in the fact that once problematic issues with neighbors have been clearly named, neighbors will not be considered competitors only and the country will not be regarded having certain internal veiled intents. Therefore, despite the nature of their autocratic regime, the idea of developing strong political and economic relations with neighboring countries had to strengthen Turkey's regional position. Besides, the vacuum of influence in the region, seeking the power of global player could have added to the change of Turkey's position, which emerged as a result of the US's intervention in Iraq, as well as the rise of anti-American sentiment in the Middle East. In the Balkans, the influence of Ankara might be limited by the EU, whereas in Caucasus a similar role was played by Russia; therefore Turkey found more favorable soil in the Middle East to express its political activeness.

\footnotetext{
${ }^{39}$ Yeșiltaş M., Balcı A., A Dictionary of Turkish Foreign Policy in the AK Party Era: A Conceptual Map, Sakarya University, SAM Papers, 2013, May, No. 7. p. 15.

${ }^{40}$ Davutoğlu, (note 26), p. 77.
} 
Turkey even established relations with its century-long competitors, mitigating diplomatic rhetoric with such countries as Greece and Armenia.

Ulutaş Ufuk states that “Turkey's zero problems with neighbors policy [...] is aimed at maximizing cooperation with its neighbors while minimizing problems in its surrounding regions" ${ }^{\text {"41 }}$; second, it sets up constructive initiatives based on political, economic, social and cultural relations in the region. Cooperation with different international entities, having various interests, poses certain challenges in seeking the "zero problems with neighbors" vision because it is extremely difficult to coordinate the diverse interests of the countries in the region while pursuing a peaceful and productive dialogue.

The "multi-dimensional foreign policy" principle means that Turkey's relations with other countries of the world should complement each other and should not be competitive. It means that it is possible to simultaneously have harmonious relations between different international players, dealing with the most complicated problems of all aspects. The paradigm grew out of the belief that Turkey could no longer follow an inactive, one-dimensional foreign policy based on a single parameter. ${ }^{42}$

Following this political principle, strategic relations between Turkey and the United States of America were essentially transformed to bilateral cooperation between the two countries and NATO. Additionally, in compliance with this principle, Turkey "considers its membership process to the EU, its good neighborhood policy with Russia, and its synchronization policy in Eurasia as integral parts of a consistent policy that serves to complete each other". ${ }^{43}$ Jordan Steckler and Darrin Altman point out that "Turkey's multidimensional foreign policy emphasizes Turkey's activism in the Middle East, Caucasia and Central Asia, the Balkan region and Africa". ${ }^{44}$ In this respect, Turkey has made progress in cooperation with Russia and Iran as well as with China and India in the continent of Asia. Advisor to the Minister of Foreign Affairs Bülent Aras noted that in the agenda of Turkish foreign policy those countries have become no less important than they were during the Cold War period; therefore, the so-called hierarchy in Turkish foreign policy no longer exists. Turkey considerably improved its activity in the Middle East region,

\footnotetext{
${ }^{41}$ Ulutaş Ufuk. Turkish Foreign Policy in 2009: A Year of Pro-activity. Insight Turkey-Commentaries, Vol.12, No 1, 2010, p. 1.

${ }^{42}$ Murat Yeşiltaş, Ali Balc1. A Dictionary of Turkish Foreign Policy in the AK Party Era: A Conceptual Map, Sakarya University, SAM Papers, 2013, May, No. 7.

${ }^{43}$ Davudoğlu, (note 26), p. 79-83.

${ }^{44}$ Steckler J.; Altman D. "Strategic depth or strategic drift?: Contending with Turkey's rapprochement with Syria and the Middle East", The Institute for Middle East Studies the Elliott School of International Affairs of the George Washington University, 2011, p.23.
} 
expanding trade relations and strengthening institutional structures. In the short and medium terms, Turkey gave priority to trade and development of cultural relations, for example, establishment of schools, newspaper publishing and other "soft power" means.

The "proactive diplomacy" principle includes crisis prevention or crisis escalation measures; in other words, preventive diplomacy. Turkish regional policy is based on such postulates as security for all, high-level political dialogue, economic integration and interdependence of the coexistence of different cultures.

The principle of "rhythmic diplomacy" has not yet found an exact conceptual equivalence in the theory of international relations. Rhythmic diplomacy is a specific style of foreign policy practiced in Turkey. It is a tactical activity that envisages simultaneous and harmonious use of diplomacy in different fields. Davutoğlu points out that "if the conditions are dynamic and one stands static, then one cannot adapt to the conditions. One needs to have a constantly moving diplomacy. That's why I call it rhythmic. In other words, even if nothing happens, one has to be active when standing". 45 Following this principle, Turkey-a non-permanent member of UN Security Council-leads three important UN committees on Afghanistan, North Korea and counterterrorism issues; it presides over the Organization of Islamic Cooperation; it acts as an observer of the League of Arab States.

Table 2 provides summarized and systematized traditional and contemporary principles of Turkish foreign policy. Currently, Turkish foreign policy is undoubtedly much more pro-active and multi-dimensional than at any time in the history of the Republic ${ }^{46}$. Turkey is undergoing a dynamic transformation process in the changing international environment - relations with Middle East countries that were rather neutral during the Cold War have considerably changed since the time when, being a loyal ally of the West, it suffered a severe failure - Europe did not approve of its full membership in the Union. Turkey is aspiring to take a central rather than peripheral status and to act in a wider geographical context. One more less conspicuous leverage of Turkey is cultural influence in Central Asia where Turkey has excellent opportunities to promote "soft power" and this greatly facilitates the establishment of the new Turkish position in the Muslim world.

\footnotetext{
${ }^{45}$ CNN Turk Special Editorial, February 17, 2004.

${ }^{46}$ Senem Aydın Düzgit \& Nathalie Tocci. Transforming Turkish Foreign Policy: The Quest for Regional Leadership and Europeanisation. Center of European Policy Studies. 12 November 2009, p. 1.
} 
Table 2. Traditional and Contemporary Principles and Factors of Turkish Foreign Policy

\section{Traditional principles of Turkish foreign policy \\ Westernization: \\ - radical rejection of the legacy of the Otto- man Empire in the entire country; \\ - a process which may be understood as acceptance and integration of Western values into Turkish society, so that even- tually the country would become part of Western civilization.}

\section{Secularization:}

- Turkish secularism had to declare neutrality of the state and political structures regarding world outlook because "Islam" and "civilization" were perceived as two opposite terms;

- Islam is not a state religion, and laicism is established in the Constitution;

- The Islamic culture would be assessed as a source of the backwardness and weakness of the Turks.

\section{Tanzimat syndrome:}

- the imperative of the Tanzimat syndrome is the delegation of collective and individual rights;

- it focuses on domestic politics and independently identifies potential Western collaborators in Turkey. These potential Western collaborators were usually identified as Christian minorities (Armenians and Greeks), representatives of Muslim, but not Turkish, communities (Arabs and Kurds); some Muslims and Turks - westernized segments of society;

- In the European standards of individual and minority rights Turkish politicians in the backstage try to discern concealed attempts of Western countries to revive terms of the Sèvres Treaty, i.e. by peaceful means get what they could not achieve by the force of arms nine decades ago.

\section{Principles of Turkish foreign policy}

after 2002

\section{"Strategic depth" doctrine:}

- geopolitical analysis;

- national value in foreign politics is determined by the nation's:

- geopolitical position. Turkey is among "geocultural basins", such as the Middle East and the Muslim world and the West (Europe and the United States) and Central Asia.

- historical origins. Cultural legacy and unity of the Ottoman Empire.

\section{Foreign policy principles of the "strategic}

depth" concept:

- "Security and freedom balance".

- Legitimate authority and political regime legitimacy depend on the ability of the authorities to grant citizens' security; however, security should not be sought by trampling on human rights and freedoms in the country.

"Zero problems with neighbors" principle:

- while distancing from regional isolation, the role of regional leadership is increasingly strengthening;

- by clearly defining cooperation problems, Turkey cannot regard its neighbors as mere rivals;

- the idea to develop strong political and economic relations with neighboring countries. 
Sèvres syndrome:

- isolationism in the field of foreign policy;

- geographic determinism;

- various fears (encirclement, loss of territory, denunciation of sovereignty) were incorporated in Western foreign policy orientation aiming at complete integration with Western institutions;

- The basis of the Sèvres syndrome was that Europeans perceive the Turks as oppressors of Christian nations of Europe and illegitimate invaders living in Christian lands of Europe.
"Multidimentional politics or multiple vec-

tors" principle:

- The awareness of needs and constant discussion of this issue and the highest level of flexibility in requiring from and negotiating with the other party (Davutoğlu).
Status quo principle to maintain the established order and balance as well as the existing borders with neighbors without interfering in regional matters.

"Proactive diplomacy" principle:

- denounce the West-oriented policy and replace it by a multi-dimensional foreign policy discourse, envisaging the development of equal relations with all regional and global players;

- Turkey is trying to improve its relations by developing commercial relationships and enhancing institutional structures;

- in short and medium term, Turkey has to give priority to trade and development of cultural relations.

\section{Caution principle regarding Turkey's} uncertainty about its authorizations and interests in foreign policy activities, i.e. passive neutrality dominated.
"Rhythmic diplomacy" principle:

- Turkey has to assume a more active role in the development of international relations;

- actively participate in all international organizations and in the discussion of all problems of international and global importance;

- use constantly "moving" diplomacy;

- seek significant new spheres of influence.

Thus, it is possible to state that in the contemporary world, having gradually overcome outdated political concepts of the twentieth century, transformation of nationalist Turkey into a multinational and multicultural state seems to be suitable enough for its ambition to perform a major role in dealing with Middle East and Eastern European issues. Turkey's new regional activeness and its economic and political potential have enabled it to seek and ensure peace and regional development. 


\section{Conclusions}

Considering present-day characteristics of Turkish foreign policy, analysis of the "strategic depth" doctrine has revealed the following aims of Turkish foreign policy:

- first, addressing issues of a wider geopolitical context in international politics;

- second, formation of a new mentality, taking into account foreign policy priorities and principles which would encourage Turkey to assume new responsibilities;

- third, transformation of the political and diplomatic environment in the neighboring areas, using a new model of foreign policy.

Landmarks and directions of the Turkish foreign policy model arise from the standpoints of domestic policy and ideology. This guarantees the continuity and strength of Turkish foreign policy because it is strategically oriented towards the economic, cultural and national security areas. With regard to this, it is obvious that Turkey is interested in strengthening structures of political, economic and cultural cooperation within the Middle East region. It is trying to unite Arab states into a single common entity, and at the same time ensuring for itself the central economic and political position in the Middle East region. However, using "the zero problems with neighbors" foreign policy, Turkey should gain greater support from other powerful global players. There is increasing confrontation among neighboring nations and governments, and "the strategic depth" doctrine is based primarily on the interests, the management of which is substantiated by the attempt to seek stability and friendly relations with neighboring governments.

Considering long-term stability in the Arab world and the eventual democratic image(s) of these countries, it is worth taking a risk and giving prominence to the influence of Turkey in the future of the EU. However, a consequence of the unprincipled EU policy regarding Turkey is that Brussels is perceived as hypocritical and egotistical by the majority of Turks. Having started negotiations with the EU in 2005, Turkey has shown progress in democratization processes. However, in 2013 the process of Turkey's accession to the EU was stopped again because of a stalemate on certain aspects in Turkish-EU relations, and though today some significant issues would be impossible to resolve, this may be explained by the unwillingness of both the sides to look for possibilities set by the bureaucratic apparatus, which was the 
cause of the non-constructive dialog. "One single flower does not mean spring has arrived", said Davutoğlu at a press conference in $2013^{47}$. It is essential, however, that the existing problems and challenges have been acknowledged by the AKP government and they are being addressed, by seeking constructive combinations and ideas.

Vilnius, June-September 2013

${ }^{47}$ Conference of Ministry for EU Affairs 'Rethinking Global Challenges: Constructing a Common Future for Turkey and the EU” Istanbul, Turkey 7 June 2013, p.4. 